\title{
The Knowledge and Experience of Nursing Students about Occupational Health and Safety
}

\author{
Ayten Kaya ${ }^{1}$, Hacer Gök Uğur ${ }^{2}$ \\ ${ }^{1}$ Lecturer, Department of Elderly Care, İkizce Vocational College, Ordu University, Ordu, Turkey \\ ${ }^{2}$ Lecturer, Department of Public Health Nursing, the Faculty of Health Sciences, Ordu University, Ordu, Turkey
}

Received: 26 September 2019, Accepted: 12 November 2019, Published online: 31 December 2019

(C) Ordu University Institute of Health Sciences, Turkey, 2019

\begin{abstract}
Objective: This study was conducted to find out the knowledge and experience of student nurses on occupational health and occupational safety.

Methods: This descriptive study was conducted on nursing students studying in the Health Sciences Faculty of a University between 26 May and 16 June 2017. The universe of the study consisted of all students studying in the department of nursing ( $\mathrm{N}=446)$, while the sample consisted of 332 student nurses determined according to "Raosoft" sample size calculation program. The data were collected through face to face interview technique with "Questionnaire Form" developed by the researchers.

Results: It was found that $76.5 \%$ of the student nurses in the study were trained about occupational health and safety before they went out to practice areas and $85.5 \%$ were vaccinated before they went out to clinical areas. $43.7 \%$ of the student nurses stated that they had occupational accident, $31 \%$ of these stated that they were injured with a sharp object and $67.6 \%$ stated that they did not report the accident. A statistically significant association was found between student nurses' ages, their year of study and their state of experiencing occupational accident $(\mathrm{p}<0.05)$.

Conclusion: It was found that almost half of the student nurses in the study underwent occupational accident, most of the reasons for occupational accidents was sharp object injury and most of the students who had occupational accident did not report these.
\end{abstract}

Key words: Student nurse, Occupation, Health, Safety, Accident

Suggested Citation: Kaya A, Gok Ugur H. The Knowledge and Experience of Nursing Students about Occupational Health and Safety. Middle Black Sea Journal of Health Science, 2019; 5(3):212-220.

\section{Address for correspondence/reprints:}

Hacer Gök Uğur

Telephone number: +90 (452) 22652006432

E-mail: hacer32@gmail.com

DOI: $10.19127 / \mathrm{mbsjohs.} 625203$

Note: This study was presented as a verbal presentation at the International Congress of Black Sea Nursing Education, 1213 October 2017, Samsun/Turkey

\section{Introduction}

Occupational health and safety includes the works to maintain and increase physical, mental and social well-being of employees in all occupations (Bilir and Yildiz, 2012). Occupational health and safety is made up of two different concepts coming together. Occupational health is related with working conditions. It means the elimination of dangerous situations that can occur from equipment used in the working environment. Occupational safety includes the necessary technical, medical and legal precautions to be taken for employees not to experience physical and mental losses in the work place (Bayilmis, 2013). Each year, 2.3 million 
people are exposed to work-related accidents or diseases in the world and more than 6000 people lose their lives every day because of occupational accidents. It is reported that globally 340 million occupational accidents occur and 160 million people die due to occupational accidents each year. However, it is reported that there aren't enough notices about occupational accidents (International Labour Organization, 2018).

Since health sector is one of the most risky lines of work, occupational accidents and diseases that occur in health institutions can cause serious consequences (Akgun, 2015). People working in health sector are faced with the risk of occupational diseases, occupational accidents, injuries and death every day in their work places through the effects of biological, chemical, physical, ergonomic and psycho-social factors, mainly contagious diseases (Sagoe-Moses et al., 2005; Bilir and Yildiz, 2012). In terms of occupational health and safety, nursing is reported to be a high risk occupation globally (Aiken et al., 2002). Nurses can be exposed to occupational accidents and risk factors, mainly infectious diseases, chemical agents, physical agents and sharp object injuries not only in their occupational lives, but also during their educational life due to their limited knowledge and experience (Shiao et al., 2002; Smith and Leggat, 2005; Merlin et al., 2011; Isara and Ofili, 2012; Lauer et al., 2014; Savc1 et al., 2018). In some studies, it is stated that $28.8 \%$ to $69.8 \%$ of the students were exposed to occupational accidents during their education (Talas 2009; Togan et al., 2015; Karatas et al., 2016; Celikkalp et al., 2017; Savc1 et al., 2018).

In Turkey, with the law of Occupational Health and Safety and the regulations issued in line with this law, all health institutions, including hospitals, and health professionals and students working in these institutions were included into the scope of social security and it has become compulsory to apply the regulations related with occupational health and security (Babayigit, 2014). Within this scope, it is important to assess the knowledge and practices of student nurses about isolation precautions, their states of experiencing occupational accident and their knowledge and experiences about occupational health and safety and thus to determine factors about students and institutions in terms of occupational health and safety precautions. This study was conducted to find out student nurses' knowledge and experience about occupational health and safety.

\section{Methods}

\section{Study design population and sampling}

This descriptive study was conducted on nursing students studying in the Health Sciences Faculty of a University between 26 May and 16 June 2017. The universe of the study consisted of all students studying in the department of nursing at Health Sciences Faculty $(\mathrm{N}=446)$. The sample was chosen from the universe through "Raosoft" sample size calculation (http://www.raosoft.com/samplesize.html).

program

Although the calculation showed that there had to be 207 samples within $95 \%$ confidence interval, the study was completed with 332 students to get closer to the actual data of the population. Nursing students who actively continue their education and willing to participate were included in the study.

\section{Ethical considerations}

In terms of ethics, ethical consent was taken from Ordu University Clinical Researches Ethical Board (Decision no: 2017/68), written permission was taken from the deanship of the Faculty of Health Sciences and verbal consent was taken from the students who participated in the study.

\section{Data Collection Instruments}

The data were collected through "Questionnaire Form" developed by the researchers in line with the literature (Smith and Leggat, 2005; Talas, 2009; Karatas et al., 2016; Celikkalp et al., 2017; Savci et al., 2018). The Questionnaire Form consists of 4 parts. The first part includes 8 questions about student nurses' identifying characteristics (age, gender, year of study, having been trained about occupational health and safety, the trainer, having been trained about vaccination, reasons for getting or not getting vaccinated). The second part includes 11 questions about student nurses' knowledge and practices about isolation precautions (knowing under which circumstances personal protective equipment is to be used, being informed by nurses about the patient who has isolation precautions, making use of personal protective equipment, knowing what contact isolation is, knowing what droplet isolation is and its sign, making interventions on patients with droplet isolation, using personal protective equipment while making interventions on patients with droplet isolation, knowing about respiratory isolation and its sign, encounter with a patient with respiratory isolation, using personal protective equipment while making interventions on patients with respiratory isolation). 
The third part includes 4 questions about student nurses' characteristics related with occupational safety (thinking that the workplace has enough warning, being warned enough by instructors about occupational safety, being sensitive about occupational safety rules, being willing about receiving a course on occupational health and safety in undergraduate education). The fourth part includes 5 questions about student nurses' occupational accident characteristics (having experienced occupational accident, areas in which they experienced occupational accident, situations in which they experienced occupational accident, whether the occupational accident was reported, and the reasons for not reporting the occupational accident).

\section{Data Collection}

The data were collected by the researchers in the classroom between 15 to 20 minutes by using face to face interview technique.

\section{Data Assessment}

The data were assessed by using SPSS 20.0 program. Descriptive statistics (numbers, percentage, arithmetic mean, and standard deviation), Independent -Samples T-Test and Chisquare test were used to assess the data. Descriptive statistics were used to determine socio-demographic characteristics, isolation measures, occupational safety and occupational accident characteristics of the students. In addition, t-test and chi-square test were used to compare students' socio-demographic characteristics and occupational accident situations. Level of significance was 0.05 .

\section{Results}

Average age of the nurses in the study was 20.89 \pm 1.85 (Min:18; Max: 28), 72\% were female and $30.7 \%$ were in their first year of study. It was found that $76.5 \%$ of the student nurses had been trained about occupational health and safety before they went out to practice areas and $66.3 \%$ were found to be trained by occupational health and safety expert. $73.2 \%$ of the student nurses stated that they were trained before they went out to practice areas, $34.3 \%$ stated that they were vaccinated before they went out to practice areas and $51.2 \%$ stated that they did not get vaccinated because they were immune (Table 1).

It was found that $90.7 \%$ of the student nurses knew what isolation precautions are, $41.9 \%$ were informed by the nurses about patients who had isolation precaution in practice areas, $58.7 \%$ could make use of personal protective equipment in practice areas, 32.8\% used Surgical mask/N 95 mask while making interventions on patients with droplet isolation and $43 \%$ used Surgical mask/N 95 mask while making interventions on patients with respiratory isolation (Table 2).

It was found that $56.9 \%$ of the student nurses thought there were enough warnings about occupational safety in practice areas, $62.7 \%$ were warned enough by instructors about occupational safety and $65.1 \%$ were willing to receive course on occupational health and safety in undergraduate education (Table 3 ).

It was found that $43.7 \%$ of the student nurses experienced occupational accident and $47.5 \%$ of these had experienced occupational accident in the clinic. Of the students who experienced occupational accident, $31 \%$ had accident with a sharp object, $13.6 \%$ with a clean instrument before treatment, $13.3 \%$ while getting drug from the ampoule, $9.6 \%$ while closing the tip of the needle and while separating the needle from the injector during treatment, $9 \%$ with an instrument which had blood on, $5.1 \%$ while diluting the drugs, $4.5 \%$ during IV practices and while bloodletting, 4.2\% while throwing wastes in the waste box and while getting drug from the vial, $3 \%$ while cleaning supplies, $\quad 2.4 \%$ while giving intravenous/intramuscular drug, $2.1 \%$ due to transmission to the eye (blood, body fluid, drug, etc), $1.5 \%$ with an instrument in a friend's hand, $1.2 \%$ while giving stitches, $0.9 \%$ while transferring blood to tube and while putting on cannula. $67.6 \%$ of the student nurses stated that they didn't report the occupational accident and when the reasons for not reporting were examined, it was found that $27.5 \%$ did not report because they didn't know that they had to report, $22.4 \%$ because there was no risk of being infected by the patient, $19.3 \%$ because they did not know about the reporting process, $33.7 \%$ because they were injured with a sterile instrument, $20.4 \%$ because they were not anxious, $9.1 \%$ because they did not have time and $5.1 \%$ because they were immune (Table 4).

A statistically significant association was found between student nurses' ages, their year of study and their state of having experienced occupational accident $(\mathrm{p}<0.05)$ and as age and year of study increased, it was found that they experienced more occupational accidents (Table 5). 
Table 1. Distribution of identifying characteristics of student nurses

\begin{tabular}{|c|c|c|c|}
\hline \multicolumn{2}{|l|}{ Identifying Characteristics } & $\mathrm{N}$ & $\%$ \\
\hline \multicolumn{2}{|l|}{ Average age } & \multicolumn{2}{|c|}{$\begin{array}{c}20.89 \pm 1.85 \\
(\text { Min: } 18 ; \text { Max: } 28)\end{array}$} \\
\hline \multirow[t]{2}{*}{ Gender } & Female & 239 & 72.0 \\
\hline & Male & 93 & 28.0 \\
\hline \multirow[t]{4}{*}{ Year of study } & 1st year & 102 & 30.7 \\
\hline & 2nd year & 50 & 15.1 \\
\hline & 3rd year & 79 & 23.8 \\
\hline & 4th year & 101 & 30.4 \\
\hline \multirow{2}{*}{$\begin{array}{l}\text { Having been trained about occupational health } \\
\text { and safety before going out to practice areas }\end{array}$} & Yes & 254 & 76.5 \\
\hline & No & 78 & 23.5 \\
\hline \multirow[t]{5}{*}{ Trainer } & Instructor of the course & 32 & 9.6 \\
\hline & $\begin{array}{l}\text { Occupational health and } \\
\text { safety expert }\end{array}$ & 220 & 66.3 \\
\hline & Chief nurse & 10 & 3.0 \\
\hline & Infection nurse & 5 & 1.5 \\
\hline & Others & 4 & 1.2 \\
\hline \multirow{2}{*}{$\begin{array}{l}\text { Having been trained about vaccination before } \\
\text { going out to practice areas }\end{array}$} & Yes & 243 & 73.2 \\
\hline & No & 89 & 26.8 \\
\hline \multirow{2}{*}{$\begin{array}{l}\text { Having been vaccinated before going out to } \\
\text { practice areas }\end{array}$} & Yes & 114 & 34.3 \\
\hline & No & 218 & 65.7 \\
\hline \multirow[t]{4}{*}{ Reasons for not getting vaccinated } & I was immune & 170 & 51.2 \\
\hline & I didn't know I had to & 17 & 5.1 \\
\hline & I didn't care & 16 & 4.8 \\
\hline & Other & 16 & 4.8 \\
\hline
\end{tabular}

Table 2. Distribution of student nurses' knowledge and practices about isolation precautions

\begin{tabular}{|c|c|c|c|}
\hline Knowledge and Practices about Isolation Precautions & & $\mathrm{N}$ & $\%$ \\
\hline \multirow[t]{2}{*}{ Knowing what isolation precautions are } & Yes & 301 & 90.7 \\
\hline & No & 31 & 9.3 \\
\hline \multirow{2}{*}{$\begin{array}{l}\text { Knowing under which circumstances personal protective } \\
\text { equipment will be used }\end{array}$} & Yes & 291 & 87.7 \\
\hline & No & 41 & 12.3 \\
\hline \multirow{3}{*}{$\begin{array}{l}\text { Being informed by the nurses about patients who have isolation } \\
\text { precaution in the practice area }\end{array}$} & Yes & 139 & 41.9 \\
\hline & No & 68 & 20.5 \\
\hline & Sometimes & 125 & 37.7 \\
\hline \multirow[t]{3}{*}{ Making use of personal protective equipment in practice areas } & Yes & 195 & 58.7 \\
\hline & No & 43 & 13.0 \\
\hline & Sometimes & 94 & 28.3 \\
\hline \multirow[t]{2}{*}{ Knowing what contact isolation is } & Yes & 294 & 88.6 \\
\hline & No & 38 & 11.4 \\
\hline \multirow[t]{2}{*}{ Knowing about droplet isolation and its sign } & Yes & 294 & 88.6 \\
\hline & No & 38 & 11.4 \\
\hline \multirow[t]{2}{*}{ Making intervention on patients with droplet isolation } & Yes & 105 & 31.6 \\
\hline & No & 227 & 68.4 \\
\hline \multirow{4}{*}{$\begin{array}{l}\text { Using personal protective equipment while making intervention } \\
\text { on patients with droplet isolation }\end{array}$} & Gloves & 102 & 30.7 \\
\hline & $\begin{array}{l}\text { Surgical mask/N } 95 \\
\text { Mask }\end{array}$ & 109 & 32.8 \\
\hline & Apron & 26 & 7.8 \\
\hline & Glasses & 6 & 1.8 \\
\hline \multirow[t]{2}{*}{ Knowing about respiratory isolation and its sign } & Yes & 287 & 86.4 \\
\hline & No & 45 & 13.6 \\
\hline \multirow[t]{2}{*}{ Encounter with patients with respiratory isolation } & Yes & 144 & 43.4 \\
\hline & No & 188 & 56.6 \\
\hline \multirow{4}{*}{$\begin{array}{l}\text { Using personal protective equipment while making intervention } \\
\text { on patients with respiratory isolation }\end{array}$} & Gloves & 101 & 30.4 \\
\hline & $\begin{array}{l}\text { Surgical mask/N } 95 \\
\text { Mask }\end{array}$ & 143 & 43.0 \\
\hline & Apron & 26 & 7.8 \\
\hline & Glasses & 6 & 1.8 \\
\hline
\end{tabular}


Table 3. Distribution of student nurses' characteristics related with occupational safety

\begin{tabular}{llcc}
\hline & & $\mathrm{N}$ & $\%$ \\
\hline Thinking that there are enough warnings about occupational safety in practice areas & Yes & 189 & 56.9 \\
\cline { 2 - 4 } & No & 143 & 43.1 \\
\hline Being warned enough by instructors about occupational safety & Yes & 208 & 62.7 \\
\cline { 2 - 4 } & No & 124 & 37.3 \\
\hline Being sensitive about occupational safety & Yes & 202 & 60.8 \\
\cline { 2 - 4 } & No & 130 & 39.2 \\
\hline Being willing about receiving a course on occupational health and safety in & Yes & 216 & 65.1 \\
\cline { 2 - 4 } undergraduate education & No & 116 & 34.9 \\
\hline
\end{tabular}

Table 4. Distribution of student nurses' characteristics related with occupational accident

\begin{tabular}{|c|c|c|c|}
\hline & & $\mathrm{N}$ & $\%$ \\
\hline \multirow{2}{*}{$\begin{array}{l}\text { Having experienced } \\
\text { occupational accident }\end{array}$} & Yes & 145 & 43.7 \\
\hline & No & 187 & 56.3 \\
\hline \multirow{5}{*}{$\begin{array}{l}\text { Areas in which occupational } \\
\text { accidents were experienced }\end{array}$} & Clinical & 69 & 47.5 \\
\hline & Bloodletting & 28 & 19.3 \\
\hline & Intensive care & 11 & 7.5 \\
\hline & Emergency service & 16 & 11.0 \\
\hline & Other areas & 21 & 14.7 \\
\hline \multirow{19}{*}{$\begin{array}{l}\text { Situations in which } \\
\text { occupational accidents were } \\
\text { experienced }\end{array}$} & Injury with a sharp object & 103 & 31.0 \\
\hline & Injury with a clean instrument before treatment & 45 & 13.6 \\
\hline & Injury with an instrument which has blood on & 30 & 9.0 \\
\hline & Injury while closing the tip of the needle during treatment & 32 & 9.6 \\
\hline & Injury while separating the needle from the injector & 32 & 9.6 \\
\hline & Injury while stitching & 4 & 1.2 \\
\hline & Injury while throwing the waste in waste box & 14 & 4.2 \\
\hline & Injury with an instrument in a friend's hand & 5 & 1.5 \\
\hline & Injury during IV practices & 15 & 4.5 \\
\hline & Injury while cleaning supplies & 10 & 3.0 \\
\hline & Injury while transferring the blood to the tube & 3 & 0.9 \\
\hline & Injury while getting drug from the ampoule & 44 & 13.3 \\
\hline & Injury while getting drug from the vial & 14 & 4.2 \\
\hline & Injury while diluting the drug & 17 & 5.1 \\
\hline & Injury while giving intravenous/intramuscular drug & 8 & 2.4 \\
\hline & Injury while putting on IV cannula & 3 & 0.9 \\
\hline & Injury while bloodletting & 15 & 4.5 \\
\hline & Injury with transmission to the eye (blood, body fluid, drug, etc) & 7 & 2.1 \\
\hline & Other & 4 & 1.2 \\
\hline \multirow{2}{*}{$\begin{array}{l}\text { Having reported the } \\
\text { occupational accident }\end{array}$} & Yes & 47 & 32.4 \\
\hline & No & 98 & 67.6 \\
\hline \multirow{7}{*}{$\begin{array}{l}\text { Reasons why occupational } \\
\text { accidents were not reported }\end{array}$} & I didn't know that I had to report & 27 & 27.5 \\
\hline & Since there was no risk of infection from the patient & 22 & 22.4 \\
\hline & I didn't know about the reporting process & 19 & 19.3 \\
\hline & Since I was injured with a sterile instrument & 33 & 33.7 \\
\hline & I wasn't worried & 20 & 20.4 \\
\hline & I didn't have time & 9 & 9.1 \\
\hline & I was immune & 5 & 5.1 \\
\hline
\end{tabular}

${ }^{*}$ More than one answer was given to situations in which occupational accidents were experienced and the reasons for not reporting the occupational accident. 
Table 5. Comparison of student nurses' states of occupational accident experience and their identifying characteristics

\begin{tabular}{|c|c|c|c|c|}
\hline \multirow[t]{3}{*}{ Average age } & & & \multicolumn{2}{|c|}{ Occupational Accident Experience } \\
\hline & & & Yes & No \\
\hline & & $\mathrm{X} \pm \mathrm{SD}$ & $21.17 \pm 1.64$ & $20.66 \pm 1.97$ \\
\hline & \multicolumn{2}{|l|}{ Test $/ \mathrm{p}$ value } & \multicolumn{2}{|c|}{$\mathrm{t}=2.507 \mathrm{p}=0.013$} \\
\hline \multirow[t]{5}{*}{ Gender } & \multirow{2}{*}{ Female } & $\mathrm{n}$ & 99 & 140 \\
\hline & & $\%$ & 41.4 & 58.6 \\
\hline & \multirow{2}{*}{ Male } & $\mathrm{n}$ & 46 & 47 \\
\hline & & $\%$ & 49.5 & 50.5 \\
\hline & \multicolumn{2}{|l|}{ Test/p value } & \multicolumn{2}{|c|}{$\mathrm{X}^{2}=1.759 \mathrm{p}=0.185$} \\
\hline \multirow[t]{9}{*}{ Year of study } & \multirow{2}{*}{$\begin{array}{l}\text { 1st year of } \\
\text { study }\end{array}$} & $\mathrm{n}$ & 33 & 69 \\
\hline & & $\%$ & 32.4 & 67.6 \\
\hline & \multirow{2}{*}{$\begin{array}{l}\text { 2nd year of } \\
\text { study }\end{array}$} & $\mathrm{n}$ & 17 & 33 \\
\hline & & $\%$ & 34.0 & 66.0 \\
\hline & \multirow{2}{*}{$\begin{array}{l}\text { 3rd year of } \\
\text { study }\end{array}$} & $\mathrm{n}$ & 41 & 38 \\
\hline & & $\%$ & 51.9 & 48.1 \\
\hline & \multirow{2}{*}{$\begin{array}{l}4 \text { th year of } \\
\text { study }\end{array}$} & $\mathrm{n}$ & 54 & 47 \\
\hline & & $\%$ & 53.5 & 46.5 \\
\hline & \multicolumn{2}{|l|}{ Test/p value } & \multicolumn{2}{|c|}{$\mathrm{X}^{2}=13.325 \mathrm{p}=0.004$} \\
\hline \multirow{5}{*}{$\begin{array}{l}\text { Having been trained in } \\
\text { occupational health and safety } \\
\text { before going out to practice } \\
\text { areas }\end{array}$} & \multirow{2}{*}{ Yes } & $\mathrm{n}$ & 112 & 142 \\
\hline & & $\%$ & 44.1 & 55.9 \\
\hline & \multirow[t]{2}{*}{ No } & $\mathrm{n}$ & 33 & 45 \\
\hline & & $\%$ & 42.3 & 57.7 \\
\hline & \multicolumn{2}{|l|}{ Test/p value } & \multicolumn{2}{|c|}{$\mathrm{X}^{2}=0.077 \mathrm{p}=0.781$} \\
\hline
\end{tabular}

$t=$ Independent - samples $t$-test $X^{2}=C h i$-square test

\section{Discussion}

The findings of this study, which was conducted to find out student nurses' knowledge and experience about occupational health and safety, were discussed in line with the literature. In the study, it was found that $76.5 \%$ of the student nurses had been trained about occupational health and safety before they went out to practice areas and $66.3 \%$ had been trained by an occupational health and safety expert. In a study conducted by Talas, it was found that $84.8 \%$ of nursing students were trained about occupational health and safety, while it was found by Savc1 et al. that $90.5 \%$ of students studying in disciplines about health were trained about occupational health and safety (Talas, 2009; Savc1 et al., 2018). In addition, Togan et al. found that $22.6 \%$ of the students studying at vocational health schools were trained about occupational accidents (Togan et al., 2015). Our results are in parallel with the results in literature. It is thought that this rate was high in our study due to the fact that it is obligatory for all students studying in the field of health to be trained about occupational health and safety before beginning to work in clinical areas with the latest regulations in Turkey. In our study, it was found that $73.2 \%$ of the student nurses had been trained about getting vaccinated before going out to practice areas, $34.3 \%$ had been vaccinated and of the students who had not been vaccinated, $51.2 \%$ had not been vaccinated since they were immune and $85.5 \%$ had gotten vaccinated before going out to clinical areas. Similarly, in studies conducted on student nurses, it was found that $67.7 \%$ and $73.5 \%$ and $83.6 \%$ of the students in vocational health schools had been vaccinated for Hepatitis B (Talas, 2009; Togan et al., 2015; Karatas et al., 2016). It is thought that the high rate of being vaccinated in our study can be due to the fact that students are trained about getting vaccinated before going out to clinical areas.

In our study, it was found that the knowledge level of student nurses about isolation precautions was higher than $80 \%$; however, the rates of making use of personal protective equipment to apply isolation precautions was found to be low. Students in the field of health should know under which circumstances isolation is applied and which isolation includes what (Tayran and Ulupinar, 2011). In a study conducted by Barikani and Afaghi on Irish medical students, it was found that students had high levels of knowledge about standard isolation precautions, but they were not sufficient in terms of practice (Barikani and Afaghi, 2012). In studies conducted by Alotaibi et al. and Suliman et al. it was found that students had high level of knowledge about isolation precautions; however, organizational factors and work load influenced nurses' isolation practices and nurses had to be supported on this issue (Alotaibi et al., 2017; Suliman et al., 2018). In parallel with the literature, 
it was found in our study that student nurses had high level of knowledge about isolation precautions but they did not make enough use of personal protective equipment in clinics to apply isolation precautions. It is thought that the reason for this can be the fact that personal protective equipment are planned according to the number of health professionals.

In the study, it was found that $43.7 \%$ of the nurses had experienced occupational accident. Talas reported that $49 \%$ of nursing students had occupational accidents, Celikkalp et al. reported that nursing students in their third year of study had at least one occupational accident during their practical training and Karataş et al. reported that $28.8 \%$ of the students nurses had been injured with a sharp object (Talas, 2009; Karatas et al., 2016; Celikkalp et al., 2017). Togan et al. reported that $68.7 \%$ of the students in vocational health schools had been injured with a sharp object and Savc1 et al. reported that $69.8 \%$ of the students in health disciplines were exposed to occupational accident at least once (Togan et al., 2015; Savci et al., 2018). The results of our study are in parallel with the results of studies conducted on nurse students. In our study, it was found that nurse students experienced occupational accidents with sharp objects, with clean instruments before treatment, while getting drug from the ampoule, while closing the tip of the needle during treatment, while separating the needle from the injector, with an instrument which had blood on, while diluting the drug, during IV practices, while bloodletting, while throwing the waste in waste box, while getting drug from the vial, while cleaning supplies, while giving intravenous/intramuscular drug, with transmission to the eye (blood, body fluid, drug, etc), with an instrument in a friend's hand, while stitching, while transferring the blood to the tube and while putting on IV cannula. In studies conducted on nursing studies in literature, it was found that students experienced occupational accidents while putting on IV catheter, using scalpel, bloodletting tubes, glass material, insulin injector, suture needles, blood sugar lancet, butterfly needle, injector, clean instrument before treatment, while closing the needle tip during drug application, while closing the needle tip after injection/treatment, while disposing of the needle to the waste box, with accidental prick of an instrument with blood on it, during venous bloodletting and while putting on IV cannula (Smith and Leggat, 2005; Talas, 2009; Canli Ozer and Aydin Bektas, 2012; Karatas et al., 2016). On the other hand, Togan et al. found that students in vocational health school experienced occupational accidents through needlestick injury, while closing the tip of injection, with injection in the trash, with blood coming to eye or an open wound and as a result of injury through surgical instrument and Savc1 et al. reported that students in health disciplines experienced occupational accidents as a result of sharp object injuries, infection with contaminated bodily fluid, being exposed to x-rays and intoxication (Togan et al., 2015; Savc1 et al., 2018). In parallel with the literature, student nurses in our study were found to experience occupational accidents due to sharp object injury mostly. It is thought that this may be due to the fact that nurses do not have enough laboratory practices before they go out to clinics.

It was found that $67.6 \%$ of the student nurses did not report occupational accidents and the reasons for not reporting were being unaware of the necessity to report, no risk of transmission from the patient, not knowing about the process to report, being injured with sterile instruments, not worrying, not being able to allocate time and being immune. Smith and Leggat found that $86.1 \%$ of nursing students did not report occupational accidents and the reasons for not reporting were not knowing how to report, having minor injuries and thinking that they would get in trouble (Smith and Leggat, 2005). Talas found that $43.9 \%$ of nursing students reported occupational accidents and the reason for not reporting was because the injury was minor (Talas, 2009). Karatas et al. found that $18.7 \%$ of nursing students reported occupational accidents and the reasons for not reporting were not being aware of the procedure, the disease having a low risk of contamination and not being worried (Karatas et al., 2016). In parallel with the literature, the rates of students reporting occupational accidents were low and the reasons for not reporting were similar. It is thought that although most of the student nurses had been trained about occupational health and safety in the study, the fact that reporting process was not emphasized much caused the low rates of reporting.

It was found that student nurses' ages and years of study influenced their state of experiencing occupational accidents, while gender and being trained about occupational health and safety did not. The students were found to experience more occupational accidents as their ages and years of study increased. Similarly, Smith and Leggat found that students' rates of being exposed to occupational accident increased as their years of study increased, while their ages, genders and other characteristics did not influence their rate of experiencing 
occupational accidents (Smith and Leggat, 2005). On the other hand, unlike our results, Canli Özer and Aydin Bektas found that nursing students experienced the highest number of sharp object injuries in their second year of study and the lowest number in their fourth year of study and Karataş et al. found that nursing students experienced the highest number of occupational accidents in their second year of study and the lowest number in their fourth year of study and that gender did not influence the state of experiencing occupational accident (Canli Ozer and Aydin Bektas, 2012; Karatas et al., 2016). It is thought that the reason why student nurses experience more occupational accidents towards the last year of their study is the fact that they are exposed to more clinical environment and accidents towards the end of their study.

\section{Limitations of the study}

The study has some limitations. First of all, the fact that the study was conducted on nursing students of only one university is a limitation in terms of the generalization of the results. Secondly, since the study was conducted on first, second, third and fourth year students, it is possible that students may have forgotten the answers to some questions due to memory factor.

\section{Conclusion}

It was found that most of the student nurses in the study had been trained about occupational health and safety and had been vaccinated before they went out to practice areas. It was found that most of the students knew about isolation precautions; however, they did not make enough use of personal protective equipment. Almost half of the students stated that there weren't enough warnings about occupational safety in practice areas and it was found that most of them were willing to receive a course on occupational health and safety in their undergraduate education. It was found that almost half of the students had experienced occupational accident and most of these students had been injured with sharp objects and did not report the occupational accident. In line with these results, it is recommended to increase awareness about occupational accidents, reasons and reporting these starting from first year of study. It is recommended for instructors to have knowledge about occupational health and safety and to be supported by institutional managers, nurses and instructors so that they can observe students and help them to apply isolation precautions in practice areas.
Ethics Committee Approval: Ethics committee approval was received for this study from Ordu University Clinical Research Ethics Committee.

Peer-review: Externally peer-reviewed.

Author Contributions: Concept -AK; Design AK, HGU; Supervision AK, HGU; Materials- AK, HGU; Data Collection and/or Processing- AK, HGU; Analysis and/or Interpretation- HGU; Literature Review- AK, HGU; Writing- AK, HGU; Critical Review- AK, HGU.

Conflict of Interest: No conflict of interest was declared by the authors.

Financial Disclosure: The authors declared that this study hasn't received no financial support.

\section{References}

Aiken LH, Clarke SP, Sloane DM. Hospital Nurse Staffing and Patient Mortality, Nurse Burnout, and Job Dissatisfaction. JAMA 2002; 288(16): 1987-93. doi:10.1001/jama.288.16.1987

Akgun S. Work Accidents in Health Sector. Health Care Acad J 2015; 2(2): 67-75. doi: $10.5455 / \mathrm{sad} .2015131442264595$.

Alotaibi MM, Almasari SM, Alkadam AN, Alanazi YA, Gahtani KA. Knowledge and Compliance with Standard Isolation Precautions Among Healthcare Students in Al-Kharj Governorate, Saudi Arabia. J Health Spec 2017; 5: 162-70. doi: 10.4103/jhs.JHS_94_16.

Babayigit MA. Knowledge, attitudes and behaviors of occupational health and safety of a medical school students. Ankara: Gazi University Institute of Health Sciences. 2014.

Barikani A, Afaghi A. Knowledge, Attitude and Practice Towards Standard Isolation Precautions Among Iranian Medical Students. Glob J Health Sci 2012; 4(2): 142-6. doi:10.5539/gjhs.v4n2p142.

Bayilmiş OÜ. Assessment of occupational health and safety awareness: field survey for health care workers. Yalova: Yalova University Labor Economics and Industrial Relations. 2013.

Bilir N, Yildiz AN. Occupational health and safety. Guler C, Akın L, editors. Public Health Basic Information Book. Ankara: Hacettepe University Publications; 2012. p. 1070-103.

Canli Ozer Z, Aydin Bektas H. Needlestick Injuries During Education Period in Nursing Students in Turkey. Procedia Social and Behavioral Sciences 2012; 46: 3798-801. doi:10.1016/j.sbspro.2012.06.149. 
Celikkalp U, Varol Saracoğlu G, Tokuc B. Increase of Knowledge Level of Nursing Students About Occupational Health and Safety. Namik Kemal Medical Journal 2017; 5(1): 36-43.

International Labour Organization (ILO) statistic. 2018. [cited 2018 Aug 21]. Available from: URL: https://www.ilo.org/moscow/areas-ofwork/occupational-safety-andhealth/WCMS_249278/lang--en/index.htm.

Isara AR, Ofili AN. Prevalence of Occupational Accidents/Injuries Among Health Care Workers in A Federal Medical Centre in Southern Nigeria. West Afr J Med 2012; 31(1): 47-51.

Karatas B, Celik SS, Koc, A. Needlestick and Sharps Injuries Among Turkish Nursing Student Knowledge and Attitude. Bozok Med J 2016; 6(4): 21-9.

Lauer AC, Reddemann A, Meier-Wronski CP, Bias $\mathrm{H}$, Gödecke K, Arendt $\mathrm{M}$ et al. Needlestick and Sharps Injuries Among Medical Undergraduate Students. Am J Infect Control 2014; 42: 235-9. doi:10.1016/j.ajic.2013.08.013.

Merlin JS, Morrison G, Gluckman S, Lipschik G, Linkin DR, Lyon S. Blood and Body Fluid Exposures Among us Medical Students in Botswana. J Gen Intern Med 2011; 26(5): 561-4. doi:10.1007/s11606-010-1586-4.

Sagoe-Moses C, Pearson RD, Perry J, Jagger J. Risks to Health Care Workers in Developing Countries. N Engl J Med 2001; 345: 538-9. doi:10.1056/NEJM20010816345071.

Savci C, Şerbetci G, Kılıc Ü. Status of Health Discipline Students to Receive Training on Occupational Health and Safety and Exposure to Occupational Accident. Journal of Health and Nursing Management 2018; 5(1): 36-47.

Shiao JSC, McLaws ML, Huang KY, Guo YL. Student Nurses in Taiwan at High Risk for Needlestick Injuries. Ann Epidemiol 2002; 12: 197-201. doi:10.1016/S1047-2797(01)00303-9.

Smith DS, Leggat PA. Needlestick and Sharps Injuries Among Nursing Students. J Adv Nurs 2005; 51(5): 449-55. doi:10.1111/j.13652648.2005.03526.x.

Suliman M, Aloush S, Aljezawi M. Knowledge and Practices of Isolation Precautions Among Nurses in Jordan. Am J Infect Control 2018; Jun;46(6): 680-4. doi: 10.1016/j.ajic.2017.09.023.
Talas MS. Occupational Exposure to Blood and Body Fluids Among Turkish Nursing Students During Clinical Practice Training: Frequency of Needlestick/Sharp Injuries and Hepatitis B Immunisation. J Clin Nurs 2009; 18: 1394-403. doi:10.1111/j.1365-2702.2008.02523.x.

Tayran N, Ulupinar S. Development of A Scale Study: Validity and Reliability of A Scale Compliance with Isolation Precautions. Florence Nightingale Journal of Nursing 2011; 19(2): 8998.

Togan T, Isık B, Turan H, Ciftci O. Hand Hygiene, Occupational Accidents, Attitudes and Behaviors of Health Vocational High School Students in Aksaray City Center. Journal of Health Academics 2015; 2(1): 8-15.. 